UNRAM Law Review is licensed under a Creative Commons Attribution 4.0 International License, which permits unrestricted use, distribution, and reproduction in any medium, provided the original work is properly cited. p-ISSN: 2548-9267 | e-ISSN : 2549-2365, Open Access at : http://unramlawreview.unram.ac.id/index.php/ulr

\begin{tabular}{c|c|c|c|c|} 
Volume & Issue & Page & April & p-ISSN: 2548-9267 \\
4 & 1 & $11-16$ & 2020 & e-ISSN : 2549-2365
\end{tabular}

\title{
The Prevention on Child Sexual Tourism in Lombok (The Province of West Nusa Tenggara), by Virtue of the Act Number 35 Year 2014 Concerning the Child Protection
}

\author{
Any Suryani Hamzah \\ Law Faculty \\ Mataram University \\ Email: anyhamzah64@gmail.com \\ Mohammad Irfan \\ Law Faculty \\ Mataram University \\ Email: adindalatifah22@gmail.com
}

\begin{abstract}
There are two types of child criminals in the tourism sector, there are preferential crime and situational sexual child crime. The preferential is a crime on children sexual oriented, the perpetrator put the children as a target to satisfy their sexual demand, and they have always been looking for children in order to fulfill their sexual desire. In this sense, they take an advantage from tourism facilities to find the children particularly the child on a tourism destination. The criminal threat to the child sexual crime is regulated under criminal codes, and The act number 35 year 2014 Concerning The Child Protection. Lombok island as a tourism object face this threat. Therefore the aim of this research is to determine the prevention act conducted by the stae and communinities on the tourism section by virtue of the Act Number 35 Year 2014. The research method in this paper using empiric juridical study by conducting primary data which collected directly from the resources who are the respondent and interviewees. Further, it is completed by secondary data which collected through the library conduct. The conclussion of this study; the are numerous prevention acts conducted by the state and communities to fight against child sexual exploitation, namely; forming the group to fight against human trafficking in every village of Lombok Island, and implementating a task force in the province of West Nusa Tenggara.
\end{abstract}

Keyword: Tourism; Sexual; Child; Protection.

\section{INTRODUCTION}

The development of tourism sector in Lombok, the province of West Nusa Tenggara contributed to the wide access to every sectors in community, among other is the employment opportunity for the domestic people on the tourism area. The increased intensity of visitation in Lombok between 2018 and 2019 have an adverse effect on the child and woman in the tourism area, according to ECPAT institution, an NGO which concerned on the protection of child and women shows that between 2016 and 2018 has occurred the case of exploitation of child commercial exploitation (briefly known as ESKA) in the district of west Lombok which is Senggigi tourism destination in amount of 16 cases, it 
also found there are 706 children who are on the susceptible condition to be exploited. ${ }^{1}$ It also found the sexual exploitation in the tourism area of Kuta the district of central Lombok in amount of 57 cases and about 623 children are at risk of exploitation. The tourism destination in Kuta Mandalika is one of the destination which planning for the world tourism by presenting stadium of 2021 Moto GP.

It is pretty sad to address the data above, the impact of tourism development have arisen the children crime. The study found there are several way of the child sexual exploitation perpetrator or also called as Human Trafficking (in Indonesian short term as TPPO) on the tourism sector. For example, in the Senggigi area, a tourist took advantage through an English education for the children who are selling around the hotel where he stay at, because of the familiarity relationship between the child and the tourist, the tourist could do a sexual crimes to the child through a coercion, another mode also revealed that there is an invitation from a friend of the community as well as the social media facility on invited and introducing each other with the tourist, seems like the social media such as Facebook, Whatsapp, Twitter have opened an easier access for the prostitution business and child exploitation in tourism sector.

According to the description above it is arise a problem on how is the prevention act which done by the state and communities on the prevention of child sexual exploitation on the tourism sector by virtue of the act number 35 year 2014 ?

\section{METHOD}

This study use empiric juridital legal method. The data use in this study is primary data which collected directly from the respondent and the informan. Data also completed by secondary data which collected through the library research.

\section{ANALYSIS AND DISCUSSION}

\section{The Prevention scheme of the state and communities on the prevention of child sexual exploitation in the tourism sectors}

There are various way which found by the NGO actors who concern on the women and child protection, namely the children who selling around the tourism sector, it is appear in Senggigi beach of west Lombok district, this children are the target of tourist through a mode of photo taking and buying the product which sell by the children, however there was another intention from the tourist which after that the child was took for a simple conversation and take them to the hotel and a coercion effort in order to serve the tourist.

In accordance with the theoretical study there are two types of child sexual crimes on the tourism sector, there are preferential crime and situational sexual child crime. The preferential is a crime on children sexual oriented, the perpetrator put the children as a target to satisfy their sexual demand, and they have always been looking for children in order to fulfill their sexual desire, they took an advantage from tourism facility to find the children.

The cases of child sexual exploitation in the tourism sector revealed a various way of humanity crimes, it is also found that the crime have openly committed no longer in a private way however it was committed in the private area such as hotel, apartment and private house as the place for child sexual exploitation. ${ }^{2}$ This reality have impact on the difficulties for the law enforcement officer to detect and against this type of human trafficking. The activity

1 Lalu Rahadian, “Human Trafficking, Sisi Kelam Industri Pariwisata?” Available from: www.bisnis.com, 15 July 2019, accessed: 23 September 2019.

2 Farhana, (2012), Aspek Hukum Perdagangan Orang di Indonesia, Jakarta: Sinar grafika, P. 21. 
of human trafficking criminal in the variant way and mode which must be not included one person only. ${ }^{3}$ We assumed that there must be an organizing network syndicate who involved on the child sexual crime, this syndicate could be involved the perpetrator, pimp, even the village stakeholder on the lower level in the tourism sector.

The punishment on crime of child sexual exploitation have threatened under the criminal code by virtue of article 15 of the act number 35 year 2014, stated that every child has the rights to be protected from a sexual crime, in means that the state must do a direct handling in order to do maximum protection effort to the child who is trapped on the child sexual tourism as disclosed above.

The legal instruments which provides the protection to the children from sexual exploitation are the convention on the child rights which ratified by the Indonesian government, an addition protocol of child trafficking, child prostitution and child pornography which ratified through the act number 11 year 2012 and the act number 35 year 2014 on the amendment of the act number 23 year 2002 on the child protection. These three instruments are the law basis for the protection of a child from a sexual exploitation on the tourism sector, however both of the previous regulation only as the state obligation in immediately take an act and protect the children and erased any form of harassment including the exploitation sexual child crime in the tourism sector.

The result of the research shows the involvement of the village stakeholder which disclosed in the area of Kuta (Central Lombok), the moral gradation of lower apparatus shows that there was a mistake on the integrity and moral education in the government. It should be, they are as the patron not as someone who involved on the human trafficking cases. The strict sanctions should be punished by the government to the state servant who involved in this crime.

Through the regional government which including lower apparatus which is village government and its ranks, according to the article 23 paragraph 1 of the act number 35 year 2014 stated that "the state, government and regional government guarantees the protection, maintenance and the welfare of the child by pay attention the rights and obligation of a parent, guardian or other people which legally binding to responsible to the child. It should be the village government as the fallen edge of apparatus on lower level must have the sense on the prevention of child crime which committed by a personal even organizing group in order to involved as the main as the front guard in helping the children of tourism sector from the child sexual trafficking.

The research shows a changing method of human trafficking activity which was focused on the rural area to the urban area where the operation is easier and safe from the law enforcement. ${ }^{4}$ There are several ways to prevent a child sexual exploitation which can be done by the tourism sector community, first of all through the literation knowledge to the children through social media platform, everybody knows the influence of social media to the children is very significant, it is pushed by the easiest access of social media through phone only by buying a cheap internet quota they are able to communicate and reaching the whole world.

The reality have further open access through digital communication which is famous in the children world, including the children on tourism sector area. If we see this fact by detailed

3 www.kompas.com, "Eksploitasi Seks Anak di Bali, Lombok, dan Batam Mengkhawatirkan", Available from: https:// travel.kompas.com/read/2009/03/20/17092794/eksploitasi.seks.anak.di.bali.lombok.dan.batam.mengkhawatirkan, ac cessed: 14 August 2019.

4 Binti Mufarida, Waspadai Perdagangan Orang melalui Industri Pariwisata, Available from: www.sindonews.com, accessed: 11 August 2019 
then we will realize on one understanding to all stakeholders which collaborated in growing awareness on developing the tourism knowledge which is friendly for children.

Literacy strengthening or spreading a positive content in providing education which focus on value reinforcement, moral reinforcement is important for the children, especially to the children who has an easy access to the outside world, the children who lack on education and lack on family attention, the children who is susceptible on the economic matters and the children who is easily polarized by the hegemony of foreign culture such as the culture who come with the foreigner tourist.

The form of digital literacy strengthening could be held through various way in the cyberspace, such as forming cyber community on the anti-child trafficking, spreading a positive content in every social media, targeting every website which linked with the campaign on human rights, serving an online consultation on the children action in order to protect them from negative tourism effect.

Secondly, by handling the case of child trafficking. One of its concrete efforts is by implementing legal breakthrough to directly push the police to give a pressure to the perpetrator and take them to the jail. The matter as describe above is in accordance with the article 59 paragraph 1 of act number 35 year 2014 on the child protection. Whether the central government, the regional government and other state institutions are obliged and responsible to provide a special protection for children. The protection as mentioned under paragraph 1 are for a child who is exploited by economical background and/ or sexual, kidnapped child, trading, and/ or trafficking, child of sexual exploitation. It is clear that what is means by state institution on this regulation is Police of Republic of Indonesia who is on duty to do the legal breakthrough and move as fast as they can on doing pressure action to the perpetrator of child sexual exploitation on the focus to punish them in jail.

On handling the human trafficking case should be done in integrative way, it means that it is need the cooperation from all stakeholders. According to the IOM data stated that Indonesia is one of pedophile tourist destination country, which targeting the children on tourism area to do the sexual exploitation to the child which is called as child sexual tourism.

However, the community and polices role on handling the human trafficking could not be viewed only through the prevention act. ${ }^{5}$ The prevention which is done by the state such as forming the task force on human trafficking is one of the prevention act, where one of the duty of this task force including the campaign to stop human trafficking action, forming a group who concern with human trafficking in every village in Indonesia, socializing and a real act on against the human trafficking such as a direct dialogue with the people in community in effort to put an aware strong mindset of the danger for the one who susceptible on the human trafficking especially on the sexual exploitation of a child in the tourism sector.

The law which is applicable on human trafficking cases could be snared with the act number 21 year 2007 on the crime of child trafficking. On the effort to minimize the sexual exploitation of a child in the tourism sector, ${ }^{6}$ which then one of its answer through a revision on the act number 35 year 2014 on the child protection. It is shows the political will of the government on accountable initiative to against the human trafficking on the child sexual exploitation, however on the practice it still need further effort of the government to build up a commitment of the law enforcer who have a full skill in handling this problem.

The comparative study as the example that provides excellent protection on child sexual exploitation case such as Australia, France and America. These three countries have its

5 LM Ghandhi Lapian\& Hetty A Geru, (2010), Trafikking Perempuan dan anak, Buku Obor, Yayasan Obor Indone sia, Jakarta: Yayasan Obor Indonesia, P. 1.

6 Henny Nuraeny, (2011), Tindak Pidana Perdagangan Orang, Kebijakan Hukum Pidana dan Pencegahannya, Band ung: Sinar Grafika,P. 273 
own way on prevent and against the sexual crime to the children, for example this country has a data base and accurate storage of the criminal of child harassment. ${ }^{7}$ This data will be used by the law enforcer as a basis if there is a child sexual harassment case which happen again in the future and this data will be informed to the other state with purpose so the perpetrator will be banned and rejected in entering other state tourism destination. This breakthrough could be example for the law enforcer in Indonesia particularly to the police and migration party who has the authority for this matter so that the protection of a child as the victim on tourist sexual crime could be minimize and handle.

There are various weakness on the implementation of legal enforcement in the tourism sector which is lack on skill and commitment. Actually, the skill and ability on the investigation of child sexual crime is required, even the specialization in this type of investigation should be implemented by the police officer, including providing the certification so that the investigator has a specific and reliable ability. While during all this time the investigator has been on rolling duty in every unit, it causes them on having a lot of skill but is not specific.

It is no longer a secret, an incentive always become the main problem on the implementation of legal enforcement moreover this is concerning the sexual harassment of a child who is committed by the tourist which is need a special budget allocation in order to do it right and programmed of what can be done. They will do a lot of investigation and rescuing the tourism destination from the child sexual 1 crime, they should not be just sitting and waiting for a report in the office however they needs to put their ears and look out for an accurate information from every informant in the tourism destination. Therefore, the investigator who choose this field should be provides a special incentive so that they could focus on handling and caring the tourism destination from the child sex offender.

\section{CONCLUSION}

The perpetrators of human trafficking crimes particularly concerning the child sexual crime is regulated under the act number 35 year 2014 on child protection. According to this regulation, it is shows the government political will to fight against the exploitation of child sexualize, however in the practice it still need further step of the government and community in commitment to enforce the law through the skilled legal enforcer to solve this problem.

The various mode of the human trafficking crime in the area of tourism sector has opened the awareness of the law enforcer and the human rights observer to intensively fight against the trafficking mode and child harassment on the tourism sector. The prevention has done by several method such as forming the group which acted to against the human trafficking in every village of Lombok island. The other effort also by implementing a task force in the province of West Nusa Tenggara as the strategy and concrete step on preventing the human trafficking case especially to the child in the tourism sector.

\section{Bybliography}

Farhana. (2012). Aspek Hukum Perdagangan Orang di Indonesia. Jakarta: Sinar grafika

Henny Nuraeny, (2011). Tindak Pidana Perdagangan Orang. Kebijakan Hukum Pidana dan Pencegahannya. Bandung: Sinar Grafika

LM Ghandhi Lapian\& Hetty A. Geru. (2010). Trafikking Perempuan dan anak, Buku Obor.

7 Ahmad Sofian, Penegakan Hukum Wisatawan Pelaku Kejahatan Seksual Anak, Available from: www.businesslawbi nus.ac.id, accessed: 27 August 2019 
Jakarta: Yayasan Obor Indonesia

Ahmad Sofian. (2019). Penegakan Hukum Wisatawan Pelaku Kejahatan Seksual Anak. Available from: www.businesslawbinus.ac.id [Accessed: 27 August 2019].

Binti Mufarida. (2019). Waspadai Perdagangan Orang melalui industri pariwisata. Available from: www.sindonews.com [Accessed: 11 August 2019].

Lalu Rahadian. (2019). Human Trafficking, Sisi Kelam Industri Pariwisata?. Available from: www.bisnis.com. 15 Juli 2019 [Accessed: 23 September 2019].

www.kompas.com. Eksploitasi Seks Anak di Bali, Lombok, dan Batam Mengkhawatirkan. Available from:https://ravel.kompas.com/read/2009/03/20/17092794/eksploitasi. seks.anak.di.bali.lombok.dan.batam.mengkhawatirkan 